\title{
PENERAPAN MODEL PEMBELAJARAN COOPERATIVELEARNING “THINK TALK WRITE” DALAM MENULISCERITA FANTASI PESERTA DIDIK KELAS VII-F SMPN 1 WONOAYU SIDOARJO
}

\author{
Riski Vidiyanti \\ Program Studi Pendidikan Bahasa dan SastraIndonesia \\ Fakultas Keguruan dan Ilmu PendidikanUniversitas PGRI Adi Buana Surabaya \\ riskividiyantis@yahoo.co.id \\ Tri Indrayanti \\ Program Studi Pendidikan Bahasa dan SastraIndonesia \\ Fakultas Keguruan dan Ilmu PendidikanUniversitas PGRI Adi Buana Surabaya Email: \\ Indrayant.tri@gmail.com
}

\begin{abstract}
The purpose of this study is that students are able to write fantasy stories through the Think Talk Write learning model. The researcher applies a Think Talk Write learning model that is applied to students of class VII-F Wonoayu Sidoarjo 1 Junior High School. Researchers use the application of learning models, namely learning Think Talk Write. This learning model helps students to get maximum learning outcomes in groups so as to foster a sense of family and cooperation. Learning to write fantasy stories was chosen as the study material because it had not yet achieved the ability of students to write fantasy stories. This is based on learning outcomes that have not yet reached the expected KKM.
\end{abstract}

Keywords: Writing, Fantasy Stories, Think TalkWrite models.

\section{PENDAHULUAN}

Pembelajaran yang selama ini digunakan oleh pendidik dalam menulis cerita fantasi adalah pembelajaran secara individual, artinya peserta didik diberikan beban untuk berpikir sendiri kemudian menuliskan apa yang ada dipikirannya tanpa berkomunikasi atau bertukar pikiran dengan teman. Hal ini menyebabkan peserta didik mengalami kesulitan dalam belajar karena ada kendala yang tidak dapat dikomunikasikan dengan teman. Tugas pendidik di kelas adalah memberikan rangsangan agar peserta didik mampu mengeksplor lebih jauh pembelajaran yang akan ditempuh.

Melihat dari permasalahan tersebut di atas peneliti akan menerapkan model pembelajaran
Think Talk Write (TTW) dalam menulis cerita fantasi agar lebih menarik minat dan keaktivan peserta didik dalam belajar. Pendidik dapat menerapkan model pembelajaran TTW untuk menarik perhatian dan minat peserta didik dalam belajar muatan pelajaran Bahasa Indonesia agar tidak membosankan. Penerapan model pembelajaran TTW memiliki tujuan untuk melibatkan semua peserta didik di dalam kegiatan pembelajaran agar semua peserta didik menjadi aktif di dalam kelas serta semangat mengikuti muatan pelajaran Bahasa Indonesia. Selain itu juga, penerapan model pembelajaran TTW dapat melatih kecakapan bicara peserta didik, kecepatan membaca peserta didik, dan memahami materi yang diajarkan dengan cepat. Pendidik 
sendiri terkadang masih merasa kebingungan untuk menyampaikan materi pelajaran, terutama pada muatan pelajaran Bahasa Indonesia. Pendidik seringkali kehabisan cara untuk menyampaikan muatan pelajaraan Bahasa Indonesia yang pada dasarnya lebih banyak materi tentang menulis yang dapat menimbulkan rasa bosan peserta didik untuk mempelajari materi pelajaran tersebut.

Penerapan

model

pembelajaran TTW pada proses pembelajaran dapat berpengaruh positif terhadap kompetensi peserta didik dalam muatan pelajaran Bahasa Indonesia. Melalui model tersebut peserta didik dapat lebih aktif dan berani dalam menjawab pertanyaan yang diberikan oleh pendidik. Peserta didik akan lebih banyak mendapatkan pengalaman dan menjadikan pembelajaran menjadi lebih bermakna sehingga nantinya dapat mempengaruhi kompetensi peserta didik dalam materi muatan pelajaran Bahasa Indonesia. Berdasarkan uraian yang telah dikemukakan di atas, maka peneliti tertarik melakukan penelitian "Penerapan Model Pembelajaran Cooperative Learning Think Talk Write dalam Menulis Cerita Fantasi Peserta Didik Kelas VII- F SMPN 1 Wonoayu Sidoarjo."

\section{METODE PENELITIAN}

Penelitian ini dilakukan di SMPN 1 Wonoayu yang berlokasi di Desa Semambung Kecamatan Wonoayu Kabupaten Sidoarjo. Subjek penelitian ini adalah peserta didik kelas VII SMPN 1 Wonoayu sebanyak 1 kelas. Prosedur pengumpulan data dalam pelaksanaan penelitian sebagai berikut:

\section{Perencanaan}

Perencanaan penelitian ini dimulai dari kegiatan melakukan pendaftaran untuk membuat surat ijin penelitian kemudian mengajukan permohonan ijin penelitian dilanjutkan dengan penyerahan surat ijin penelitian kepada kepala sekolah lalu menentukan peserta didik yang digunakan sebagai subjek penelitian. Menyusun rancangan pembelajaran yang terkait dengan penelitian yaitu berupa rencana pelaksanan pembelajaran (RPP) yang di dalamnya memuat langkah pembelajaran berupa penerepan pembelajaran Cooperaive Learning Think Talk Write.

\section{Pelaksanaan}

Pelaksanaan penelitian ini dimulai dari pendidik memberikan apersepsi awal tentang materi menulis yang akan diajarkan. Seluruh kegiatan dilakukan sesuai berdasarkan RPP yang telah disusun namun pendidik boleh memberikan improvisasi untuk menghindari kekakuan dalam pembelajaran. Melakukan observasi selama proses pembelajaran yang berlangsung yang meliputi aktivitas menulis peserta didik.

\section{Evaluasi}

Pada tahap evaluasi peneliti menjelaskan hasil dari pelaksanaan pembelajaran yang telah dilakukan di kelas berdasarkan pelaksanaan setiap siklus, tingkat keberhasilan pembelajaran serta menilai hasil kerja peserta didik yang diperoleh pada setiap akhir pembelajaran.

\section{Refleksi}

Tahap refleksi adalah tahap yang dilakukan setelah peneliti melihat hasil pengamatan yang 
dilakukan. Berdasarkan hal tersebut peneliti akan menganalisis kegiatan yang perlu diperbaiki. Tahap ini akan menjadi acuan dalam pelaksanaan penelitian selanjutnya. Dari hasil siklus 1 yang telah dilaksanakan peneliti akan mengadakan siklus 2 sebagai bahan pembanding hasil belajar dari siklus pertama sehingga dapat diketahui bagaimana perkembangan peserta didik setelah belajar dari sikluspertama.

\section{HASIL PENELITIAN}

Penyajian data yang
diuraikan merupakan teknik
penerapan model pembelajaran
Cooperative Learning Think Talk
Write (TTW) dalam menulis cerita
fantasi dan hasil belajar peserta
didik dalam menulis cerita fantasi
dengan menerapkan model
pembelajaran TTW.

\section{Penerapan \\ Model \\ Pembelajaran Cooperative \\ Learning Think Talk Write dalam Menulis Cerita Fantasi}

\section{Siklus 1}

\section{a. Perencanaan}

Kegiatan dan bahan yang dipersiapkan oleh peneliti dalam melaksanakan tindakan ini adalah menyusun rancangan pembelajaran yang terkait dengan penelitian yaitu berupa rencana pelaksanan pembelajaran (RPP) yang di dalamnya memuat langkah pembelajaran berupa penerapan pembelajaran Cooperaive Learning Think Talk Write yang telah dikonsultasikan dan disesuikan dengan kondisi sekolah serta membuat kesepakatan dengan pendidik kelas dan peserta kelas VII-F SMPN 1 Wonoayu Sidoarjo mengenai waktu yang digunakan untuk melakukan pembelajaran. Pada kegiatan pembelajaran pendidik juga mempersiapkan alat pengamatan yaitu lembar instrumen penilaian, jurnal, lembar tes, dan lain-lain.

\section{b. Pelaksanaan}

Dalam

pelaksanaan pembelajaran ini yang dilibatkan adalah peneliti yang sekaligus berperan sebagai pendidik. Berikut akan diuraikan aktivitas peserta didik pada pelaksanaan siklus I.

Berdasarkan penerapan model pembelajaran TTW dalam menulis cerita fantasi pada siklus 1 dapat diketahui bahwa rerata hasil kerja peserta didik dalam menulis cerita fantasi hanya mencapai $61,62 \%$.

Peserta didik yang tuntas mencapai nilai $\geq 75$ hanya ada 2 kelompok dengan persentase $25 \%$, sedangkan kelompok yang tidak tuntas mencapai nilai $\geq 75$ ada 6 kelompok dengan persentase $75 \%$.

\section{c. Evaluasi}

Pada tahap evaluasi pendidik menjalaskan hasil belajar menulis cerita fantasi yang diperoleh selama pembelajaran. Hasil belajar pada siklus 1 belum memenuhi KKM pelajaran Bahasa Indonesia. Sehingga perlu dikaji ulang dan dilakukan siklus 2 .

\section{d. Refleksi}

Pada tahap refleksi, hasil belajar yang diperoleh dalam menulis cerita fantasi diolah dan dianalisi untuk diberikan tindakan siklus 2. Selanjutnya dievaluasi dan didiskusikan mengenai kekurangan yang perlu diperbaiki untuk dijadikan bahan perencanaan pada siklus 2.

\section{Siklus 2}

\section{a. Perencanaan}

Pertemuan siklus 2 dilaksanakan sebagai kelanjutan pertemuan siklus 1 terutama jika terjadi kekurangan dalam 
perencanaan pertemuan siklus 1 . Kekurangan itu berupa situasi kelas berubah, perkembangan baru, kondisi siswa, dan materi pelajaran. Perencanaan tindakan pada siklus 2 ini tetap sesuai dengan tindakan pada siklus 1 namun ada perubahan pada materi ajar yaitu dengan merubah tema tugas menulis cerita fantasi supaya peserta didik lebih terarah.

\section{b. Pelaksanaan}

Pelaksanaan siklus 2 dilakukan sesuai dengan rencana yang telah ditetapkan pendidik dan peneliti mengenai pembelajaran menulis cerita fantasi sebagaimana pelaksanaan sesuai siklus 1 .

Rerata hasil kerja peserta didik dari $61,62 \%$ menjadi $75,62 \%$. Peserta didik tuntas mencapai nilai $\geq 75$ dari

2 kelompok dengan persentase $25 \%$ menjadi 6 kelompok dengn persentasi $75 \%$. Sehingga nilai peserta didik yang telah mencapai KKM yaitu 75 mengalami kenaikan setelah dilakukan siklus 2 .

Berdasarkan penerapan model pembelajaran TTW dalam menulis cerita fantasi siklus 2 tersebut dapat diketahui bahwa terjadi peningkatan hasil belajar peserta didik dari siklus 1 ke siklus 2.

\section{c. Evaluasi}

Pada tahap evaluasi pendidik menjalaskan hasil belajar menulis cerita fantasi yang diperoleh selama pembelajaran pada siklus 2. Hasil belajar pada siklus 2 sudah mengalami peningkatan dalam menulis cerita fantasi dari hasil siklus 1 sebelumnya.

\section{d. Refleksi}

Pada tahap refleksi, hasil belajar yang diperoleh dalam menulis cerita fantasi pada siklus 2 adalah peserta didik sudah memenuhi KKM pelajaran Bahasa Indonesia. Aktivitas peserta didik dalam belajar sudah mengarah ke model TTW dan peserta didik sudah mampu membangun kerja sama dalam kelompok.

\section{Hasil belajar peserta didik dalam menulis cerita fantasi dengan menerapkan model pembelajaran Cooperative Learning Think Talk Write.}

a. Hasil belajar pada siklus 1

Peserta didik yang tuntas mencapai nilai $\geq 75$ hanya ada 2 kelompok dengan presentase $25 \%$, sedangkan kelompok yang tidak tuntas mencapai $\geq 75$ ada 6 kelompok dengan persentase $75 \%$. Hal demikian terjadi karena masih banyak peserta didik yang belum memahami apa yang dimaksud dengan teks fantasi, sehinga masih banyak peserta didik yang belum mengetahui cara menyusun teks fantasi. Dari persentase diatas dapat diketahui kemampuan peserta didik sebagian besar masih rendah. Hal ini dilihat dari persentase rata-rata $61,62 \%$ dan masih di bawah KKM yang di tetapkan SMP Negeri 1 Wonoayu Sidoarjo yakni 75 (Penghitungan terlampir).

b. Hasil belajar pada siklus 2

Berdasarkan hasil belajar diatas dapat diuraikan hasil belajar peserta didik tuntas tuntas mencapai nilai $\geq 75$ ada 6 kelompok dengan persentase $75 \%$, sedangkan kelompok yang tidak tuntas mencapai $\geq 75$ ada 2 kelompok dengan persentase $25 \%$. Hal demikian terjadi karena adanya perubahan tema menulis dari siklus 1 ke siklus 2. Dari persentase di atas dapat diketahui kemampuan peserta didik sebagian besar sudah bertambah. Hal ini dilihat dari persentase rata- rata dari $61,62 \%$ 
menjadi $75,62 \%$ dan telah mencapai KKM yang di tetapkan SMP Negeri 1 Wonoayu Sidoarjo yakni 75 (Penghitungan terlampir)

\section{PEMBAHASAN}

Dari hasil analisis siklus 1 dapat dilihat bahwa hasil belajar peserta didik masih tergolong kategori cukup yaitu mencapai nilai rerata $61,62 \%$. Sehingga dilakukan aktivitas siklus 2 dengan hasil nilai rerata $75,62 \%$ yang tergolong kategori baik. Selain hasil penelitian, pada bab ini juga dijelaskan mengenai pembahasan dari penelitian yang sudah dilaksanakan. Berdasarkan pertayaan penelitian yang telah dikemukakan peneliti yaitu pertanyaan penelitian pertama adalah "Bagaimana teknik penerapan model pembelajaran Cooperative Learning Think Talk Write dalam menulis cerita fantasi peserta didik kelas VII-F SMPN 1 Wonoayu Sidoarjo?", Kemudian pertanyaan penelitian kedua yaitu "Bagaimana hasil belajar yang diperoleh peserta didik kelas VII-F SMPN 1 Wonoayu Sidoarjo dalam menulis cerita fantasi dengan menerapkan model pembelajaran Cooperative Learning Think Talk Write?". Pada data hasil penerapan model pembelajaran Cooperative Learning Think Talk Write dalam menulis cerita fantasi

\section{SIMPULAN}

Berdasarkan temuan yang didapatkan dari penelitian tentang "Penerapan Model Pembelajaran Cooperative Learning Think Talk Write dalam Menulis Cerita Fantasi Peserta Didik Kelas VII-F SMPN 1 Wonoayu Sidoarjo.”, dapat ditarik kesimpulan bahwa Penerapan Model Pembelajaran Cooperative
Learning Think Talk Write dalam Menulis Cerita Fantasi memiliki tujuh fase yang telah dikembangkan dengan sintak model pembalajaran TTW serta memiliki penilaian secara umum baik dan layak digunakan.

Penerapan

Model

Pembelajaran Cooperative

Learning Think Talk Write dalam Menulis Cerita Fantasi Peserta Didik Kelas VII-F SMPN 1 Wonoayu Sidoarjo dilakukan dalam dua siklus. Pelaksanaan siklus 1 dan siklus 2 memperoleh hasil yang berbeda. Pada siklus 1 diperoleh hasil nilai rerata $61.62 \%$ dan siklus 2 diperoleh hasil nilai rerata 75,62\%. Peserta didik memperoleh hasil yang baik. Hal itu dapat dilihat dari persentasi yang mengalami kenaikan nilai rerata sebesar $14 \%$.

\section{DAFTAR PUSTAKA}

Daryanto. 2009. Panduan Proses Pembelajaran

Kreatif\&Inovatif. Jakarta: Publish.Departemen.

Harsiati. 2017. Bahasa Indonesia SMP/MTs edisi revisi. Jakarta: Kementrian Pendidikan dan Kebudayaan.

Huda, Miftahul. 2013. Modelmodel pembelajaran. Yogyakarta: PustakaPelajar.

Hoetomo M.A. 2015. Kamus Lengkap Bahasa Indonesia. Surabaya: Mitra Pelajar.

Kemendikbud. 2015. Buku Saku Gerakan Lieterasi Sekolah. Jakarta: Kemendikbud.

Mulyati, $\quad$ Yeti. 2015. KeterampilanBerbahasa Indonesia SD. Jakarta: Universitas Terbuka.

Nafisah, Durratundkk. 
KarakteristikCeritaFantasiA nak Indonesia Periode 20002010, Online, http://JurnalOnline.um.ac.iddiunduh 23 Agustus 2018 pukul 21.00. Nurgiyantoro, Burhan. 2016. Sastra Anak. Yogyakarta: Gadjah mada University Press.

Ryanti, Widya Okta. Penerapan Model Pembelajaran Think Talk Write untuk Meningkatkan Aktivitas dan Hasil Belajar Siswa Kelas V Pada Mata Pelajaran IPS SD Negeri 9 Metro Timur Tahun Pelajaran 2015/2016. Skripsi. Universitas Saputri, Vioni dkk. Kemampuan Menulis Cerita Fantasi dengan Model Mind Mapping kelas VII-2 SMP Negeri 21 Batanghari Tahun Ajaran2017/2018.

Sudjana, nana. 2011. Penilaian Hasil Proses Belajar. Bandung: PT Remaja Rosdakarya.

Sugiyono. 2012.

MetodePenelitianPendidika $n$. Bandung: Alfabet.

2015. MetodePenelitianPendidika $n$. Bandung: Alfabet. 2017. MetodePenelitianPendidika $n$. Bandung: Alfabet.

Suparnodan

Muhammad

Yunus.2008.

KeterampilanDasarMenulis.

Jakarta: Universitas

Terbuka.

Suprijono, Agus. 2010. Cooperative Learning Teori dan Aplikasi PAIKEM. Yogyakarta: Pustaka Belajar.

Tarigan, Henri Guntur. 2008. MenulissebagaiSuatuKetera
mpilanBerbahasa.

Bandung: PenerbitAngkasa. 